\title{
Reproductive biology of blue runner, caranxcrysos (Mitchell, I8I5) from the Coastal Waters of Rio Grande do Norte, Brazil (Southwest Atlantic Ocean)
}

\begin{abstract}
Reproductive biology of blue runner, Caranx crysos was investigated, based on the total body length, body weight, sex ratio, size at first sexual maturity, macroscopic developmental stages of gonads, ovarian histology, gonadosomatic index (GSI), fecundity and the spawning season. The length-weight relationship for grouped sex was $\mathrm{W}=0.0346 . \mathrm{LT} 2.6717$. The sex ratio of the sampled population $(\mathrm{n}=116)$ was $1: 1.1$ without any significant difference from the expected sex ratio. First sexual maturation in males and females occurred at $331 \mathrm{~mm}$ of total body length. The macroscopic characteristics of gonad development indicated immature, maturing, mature and spent stages. Histological analyses of ovary indicated the following oocyte developmental stages: early and late primary growth stage, cortical alveolar stage and early and late vitellogenic growth stages. GSI attained peak values from April to June and in January. Mature fish occurred during most part of the year, other than during February and October. This species has a prolonged reproductive period with peak periods of activity. C. crysos has a high reproductive output, providing population increase and exploitation of the environmental resources.
\end{abstract}

Keywords: Reproductive aspects, Maturity stages, Ovarian histology, Size at first maturity, Caranx crysos
Volume 5 Issue 6 - 2017

\author{
Sathyabama Chellappa, M nica Rocha de \\ Oliveira, Marcelo Francisco N brega, Jorge \\ Eduardo Lins Oliveira \\ Departamento de Oceanografia e Limnologia, Centro de \\ Biociências, Universidade Federal do Rio Grande do Norte \\ Brazil
}

Correspondence: Sathyabama Chellappa, Departamento de Oceanografia e Limnologia, Centro de Bioci, Email chellappa.sathyabama63@gmail.com

Received: May 29, 2017 | Published: June 08, 2017

\section{Introduction}

Off the Brazilian coast, the genus Caranx, belonging to the family Carangidae, is represented by five species: Caranx crysos (Micthill, 1815), C. ruber (Bloch, 1793), C. hippos (Linnaeus, 1766), C. latus Agassiz, 1831 and C. lugubris Poey, $1860 .{ }^{1}$ Carangid species are among the main fishing resources marketed in Brazil. C. crysos was amongst the most sampled carangid species landings during the Research Project Revizee Score-NE, Brazil. ${ }^{2}$

Blue runner, Caranx crysos is an important demersal species in the fisheries and is commonly known as blue stripe jack, Egyptians cad, hard tail jack and hard nose. It is widely distributed across the Atlantic Ocean, ranging from Brazil to Canada in the western Atlantic and from Angola to Great Britain including the Mediterranean in the eastern Atlantic. ${ }^{3}$ C. crysos is captured by using haul seines, lampara nets, purse seines, gill nets, and hook and line. ${ }^{4}$ It is a schooling fish, which inhabits both inshore and offshore environments, predominantly around large man made offshore structures, such as petroleum platforms. Juveniles of C. crysos end to inhabit shallower reef and lagoon waters whereas adults move to deeper waters. ${ }^{5}$

Information on the reproductive biology of fish is of fundamental importance to understand the life history strategy and to take necessary measures for management and conservation. ${ }^{6-9}$ There are reports on annual reproductive cycle, spawning periodicity and sexual maturity of C. crysos from the Gulf of Gabes, Tunisia, Eastern Mediterranean ${ }^{4}$ and from Porto Rico. ${ }^{10}$ Sex ratio, spawning and maturity of C. crysos from the Gulf of Mexico has been investigated. ${ }^{11}$ The reproductive biology and histological characteristics of female $C$. crysos from the Egyptian Mediterranean Sea has been studied. ${ }^{12}$ However, there is scarcity of information on the reproductive biology of C. crysos populations from Southwest Atlantic Ocean. Considering this and the importance of this species in the commercial fish landings of Brazil, the present study aimed to investigate its reproductive biology.
This study presents information on the body size, length-weight relationship, type of growth, sex ratio, length at the onset sexual maturity (L50), macroscopic developmental stages of gonads, ovarian histology, fecundity, GSI, monthly distribution of maturity stages and reproductive period of C. crysos, from the coastal waters of Rio Grande do Norte, Brazil (Southwest Atlantic Ocean).The description of the reproductive biology of C. crysos is presented in order to clarify characteristics related to its reproduction.

\section{Materials and methods}

\section{Sampling}

The state of Rio Grande do Norte is located in Northeastern Brazil and has a coast of approximately $420 \mathrm{~km}$. Specimens of $C$. crysos were captured by experimental fishing, on a monthly basis during the period of July, 2013 to June, 2014. Experimental fishing was carried out along the coast of Rio Grande do Norte, Brazil (situated between latitudes $4^{\circ} 40^{\prime} 0^{\prime \prime}$ S e $6^{\circ} 20^{\prime} 0^{\prime \prime} \mathrm{S}$, longitudes $37^{\circ} 0^{\prime} 0^{\prime}$ ' and $35^{\circ} 0^{\prime} 0$ ' W).

Fishing operations were carried out at depths ranging from 5 to 52 $\mathrm{m}$ utilizing vessels of the artisanal fleet, which operate with bottom gillnets. The nets were made of monofilament nylon and were set on the bottom of the sea. The length of the fishing nets varied from 800 to $3600 \mathrm{~m}$, with mesh size varying from 45 to $60 \mathrm{~mm}$ and about 2 meters in height. Gillnets were set in the late afternoon on the bottom of the sea and were collected approximately two hours later.

Captured fish were numbered, total length of each fish was measured to the nearest millimeter ( $\mathrm{Lt} \pm 1 \mathrm{~mm}$ ) and total body weight was measured to the nearest gram $(\mathrm{Wt} \pm 1 \mathrm{~g})$. Morphometric measurements and meristic counts were carried out on fish to confirm the taxonomy of the study species using the identification keys. ${ }^{13}$ Fish were brought to the laboratory on ice were and dissected. The location and general aspects of the gonads were observed. After which, the gonads were removed, weighed $(\mathrm{Wg} \pm 0.1 \mathrm{~g})$, and sex identified. The 
stage of reproductive maturity was verified by characteristics, such as colour, shape, space occupied in the coelomic cavity and presence of visible oocytes. ${ }^{6}$ Immature individuals were not included as it was not possible to determine their sex by macroscopic observation.

\section{Size range and Length-weight relationship}

Distribution analysis of total length and weight of each fish was performed using the absolute frequencies (mean $\pm \mathrm{SD}$ ) in different classes of total length $(\mathrm{Lt})$ and total weight $(\mathrm{Wt})$. The total length data of males and females was grouped into class intervals of $50 \mathrm{~mm}$. The length-weight relationship was determined by the equation $\mathrm{Wt}=\mathrm{a}$. $\mathrm{Ltb}$, where $\mathrm{Wt}$ is the total weight $(\mathrm{g}), \mathrm{Lt}$ is the total length $(\mathrm{cm})$, a is the intercept and $b$ is the coefficient of growth or regression. ${ }^{14}$ The Huxley's equation ( $\mathrm{W}=\mathrm{a} . \mathrm{Lb}$ ) was used to adjust length-weight model. $^{15}$

\section{Sex ratio}

Sex ratio between males and females (M:F) was obtained through the relative frequency distribution analysis of males and females during the study period.

\section{Length at first sexual maturity}

Body size at first gonadal maturity (L50) where $50 \%$ of the individuals exhibited maturing gonads was estimated from the relative frequency distribution of adult males and females, using their standard length classes $($ mean $\pm \mathrm{SD}){ }^{16}$

\section{Macroscopic description and histology of gonads}

The macroscopic developmental stages of gonads were determined by their characteristics. ${ }^{17,6}$ Fragments of female gonads selected for histological analysis were fixed in Bouin solution for 12$24 \mathrm{~h}$ (depending on size), washed for 24 hours in running water to remove excess fixative and were later preserved in $70 \%$ Ethyl alcohol. Fragments of ovaries were embedded in paraffin, sectioned at 3-5 $\mu \mathrm{m}$ thickness, and stained with Hematoxylin-Eosin (HE) and periodic acid Schiff (PAS). The histological description of the developmental stages and classification were performed using the existing terminology. ${ }^{18,19}$

\section{Fecundity}

The oocytes from mature ovaries were dissociated using Gilson solution, and three sub-samples of $0.1 \mathrm{~g}$ were extracted. The oocytes were counted using Bogorov counting chamber, a stereomicroscope and an ocular micrometer. Total fecundity was estimated for the total weight of the ovaries. Fecundity $=[$ (number of mature oocytes in the fragments of ovary) $\mathrm{x}$ (total weight of ovary)] / (weight of the fragment of the ovary). ${ }^{20,21}$

\section{Gonadosomatic index (GSI) and reproductive period}

The gonadosomatic index (GSI) was calculated as: GSI = weight of ovary (g) / body weight of fish (g) - weight of gonads ( $\mathrm{g}) \times 100 .{ }^{22}$ The breeding period was determined by the temporal relative frequency distribution of the different stages of gonadal maturation. ${ }^{23}$

\section{Statistical analyses}

Distributions of raw data were checked for normality and transformed when necessary. Pearson correlation tests were conducted to determine the correlation between weight and length. The chi-square $\left(\chi^{2}\right)$ test was applied at a significance level of $5 \%$ to test any difference in the sex ratio. A Student t-test was used to verify the difference between the total length and body mass of males and females, at a significance level of 5\%. The results are presented as a mean \pm SD. Analysis of covariance (ANCOVA General Linear Models procedure) was used to test the differences between $a$ and $b$ values from males and females growth curve. Furthermore, General Linear Models ${ }^{24}$ was used to model the expected total length (normal model and identity link function). The level of significance was set at $5 \%$ for the identification of statistically significant factors and coefficients that explain the variability in the response variable in the model of GLM. The Kolmogorov-Smirnov test was used to test the normality of the estimated residuals GLMs, checking the fit of these models to the data. The proposed model has the following structure in its covariables: $\mathrm{Y}=\beta+\mathrm{Sex}+\mathrm{SM}+\mathrm{Sex} * \mathrm{SM}$ where $\beta$ is an intercept term, $\mathrm{SM}$ is a stage of maturation.

\section{Results}

\section{Body size (Length-weight) and size range}

A total of 116individuals of $C$. crysos were examined (56 males and 60 females). Number of males and females of C. crysos sampled each month is shown in Table 1.

All individuals captured were above $200 \mathrm{~mm}$ of total length. Total body length of males varied from 283 to $435 \mathrm{~mm}$ and their body weight varied from 168 to $843 \mathrm{~g}$. The total body length of females varied from 230 to $480 \mathrm{~mm}$ and their body weight varied from 136 to $1040 \mathrm{~g}$ There was no significant differences between the total body length $(\mathrm{f}=0.019, \mathrm{df}=115, \mathrm{p}>0.05)$ and body weight $(t=1.159, \mathrm{df}=$ $115, \mathrm{p}>0.05)$ of males and females. Figure 1 shows the distribution of body length and body weight classes of males and females.

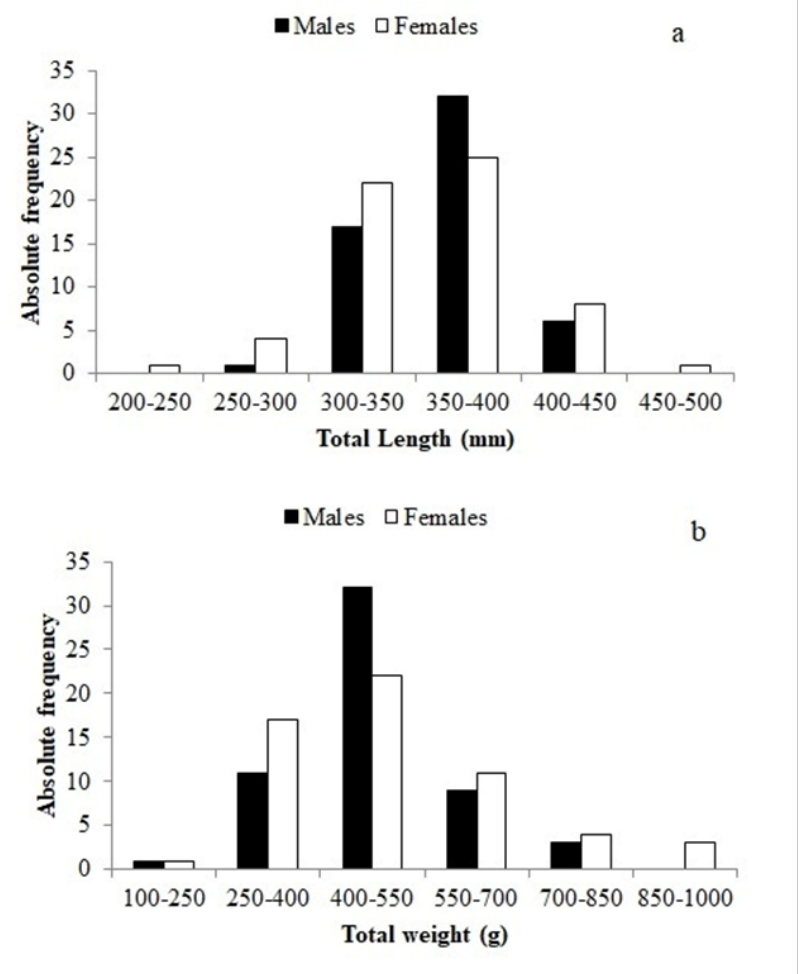

Figure I Size distribution frequency of male and female Caranx crysos during July, 2013 to June, 2014 (a) total length, (b) body weight. Data= means (columns). 
Table I Number of males and females of Caranx crysos sampled each month during July, 2013 to June, 2014 from the coastal waters of Rio Grande do Norte, Brazil

\begin{tabular}{lll}
\hline \multirow{2}{*}{ Month } & \multicolumn{2}{l}{ Total Fish sampled } \\
& Males & Females \\
\hline Jan & 7 & 5 \\
Feb & 0 & 1 \\
Mar & 6 & 3 \\
Apr & 9 & $1 \mathrm{I}$ \\
May & 6 & 12 \\
Jun & $1 \mathrm{I}$ & 4 \\
Jul & 1 & 1 \\
Aug & 4 & 3 \\
Sep & 9 & 11 \\
Oct & 1 & 1 \\
Nov & 0 & 4 \\
Dec & 2 & 4 \\
Total & 56 & 60 \\
\hline
\end{tabular}

\section{Length-Weight relationship and type of growth}

There was no significant differences between the length-weight relationship of males and females $(\mathrm{F}=3.889 ; \mathrm{p}=0.051)$. The lengthweight relationship showed positive correlation with a coefficient of determination (r2) of 0.916 for grouped sex. The length-weight relationship for grouped sex was $\mathrm{W}=0.0346 . \mathrm{LT} 2.6717$ (Figure 2).

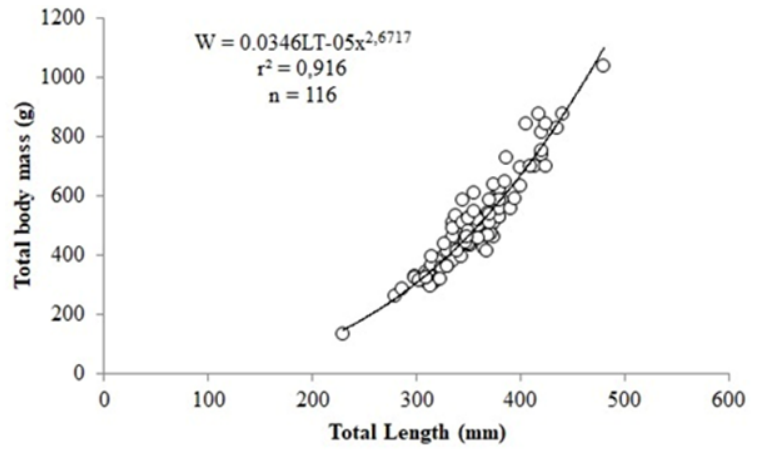

Figure 2 Length-Weight relationship for pooledsexes of Caranx crysos captured during July, 2013 to June, 20I4from the coastal waters of Rio Grande do Norte, Brazil.

\section{Sex ratio}

The sex ratio of the sampled population was 1: 1.1 without any significant difference between the sexes in relation to the expected ratio of $1 \mathrm{M}: 1 \mathrm{~F}\left(\chi^{2}=0.21\right)$. Figure $3 \mathrm{a}$ shows the distribution of the frequency of occurrence males and females on a monthly basis. Neither of the sex predominated during the study period. Figure $3 b$ shows the frequency of occurrence of males and females distributed according to total length classes. Females were more in number in the total length classes.

The GLM model established for the total length indicated that the intercept $(\mathrm{P}=1.51 \mathrm{E}-12)$ and the maturation stage $(\mathrm{P}=0.306)$ are statistically significant (Figure 1). However, sex $(\mathrm{P}=0.285)$, and the interaction between sex and maturation stages $(P=0.306)$ were not statistically significant (Table 2). The GLM model adjusted fairly to the data (Figure 2), presenting normal distribution $(\mathrm{KS}=1.265 ; \mathrm{P}$ $=0.082$ ). Since the applied test showed no significant differences in length for males and females, and the interaction of sex in relation to the maturation stages, the curve for first reproduction of the study species was estimated considering the pooled sexes.
Table 2 General results of the GLM analysis for the expected total length of Caranx crysos (normal model and identity link function)

\begin{tabular}{llll}
\hline & \multicolumn{2}{l}{ Wald Chi-Square df } & P \\
\hline Intercept & 240.09 & $\mathrm{I}$ & $\mathrm{I} .5 \mathrm{I0E}-12$ \\
Sex & $\mathrm{I} .14$ & $\mathrm{I}$ & 0.285 \\
Stageofmaturation & 7.72 & 3 & 0.005 \\
Sex * Stageofmaturation & $\mathrm{I} .05$ & 5 & 0.306
\end{tabular}
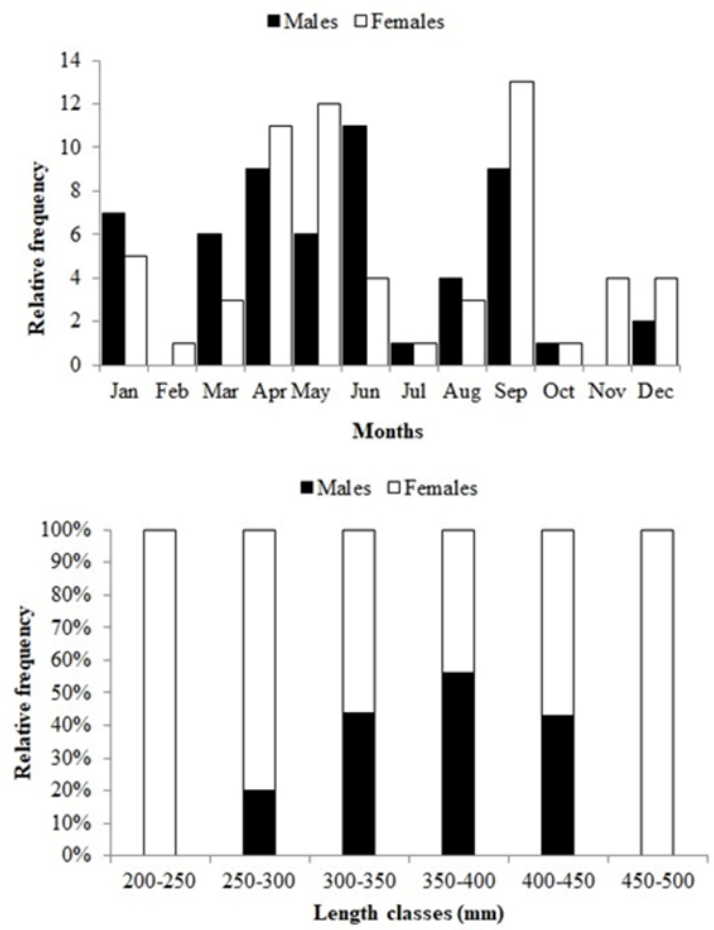

Figure 3 (a) Relative frequency of monthly values for sex ratios of Caranx crysos, (b) Relative frequency of males and females in different classes of total length.

\section{Length at first sexual maturity $\left(L_{50}\right)$}

There was no significant difference between the total body lengthsof males and females of C. crysos in relation to total body length for the first sexual maturity. The mean size when $50 \%$ of fish were in the process of sexual maturation (L50) was $331 \mathrm{~mm}$ of total body length (Figure 4).

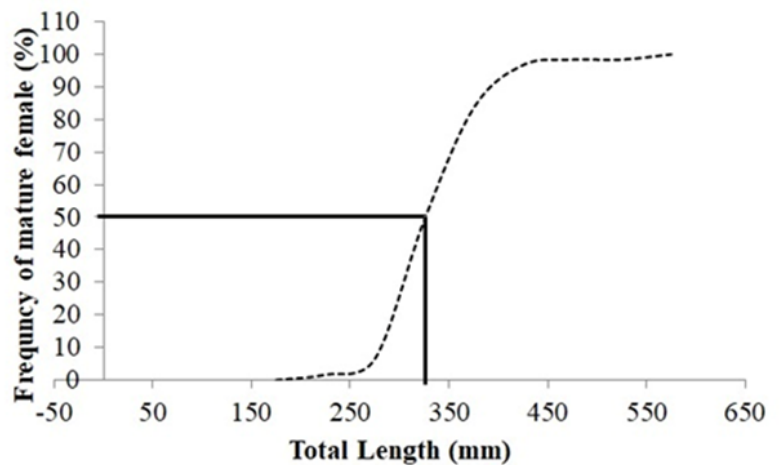

Figure 4 The cummulative percentage of observed mature fish in relation to body size for pooledsexes of Caranxcrysos(dotted line). The inserted lines represent the estimated size range where $50 \%$ of the fish were mature. 


\section{Macroscopic characteristics of gonads and frequency of maturity stages}

The macroscopic characteristics of gonads of C. crysos indicated four developmental stages for males and females: immature, maturing, mature and spent. Immature ovaries were of small size and filiform. Maturing and mature ovaries appeared reddish in colour, of increased size with visible oocytes. The spent ovaries were reduced size with flaccid appearance. Immature males were not used in this study. The testes were of different sizes according to their degree of development, became thicker and whitish in colour. The spent testes were reduced size with flaccid appearance. The macroscopic description of the ovaries and testes shows how gonadal development occurred during the reproductive cycle.

The maturity analysis for males showed that $16.7 \%$ of them were maturing, $73.21 \%$ were mature and $10.71 \%$ were spent. In the case of females, $1.61 \%$ was immature, $14.51 \%$ were maturing, $61.29 \%$ were mature and $22.58 \%$ were spent. Figure 5 shows the distribution of monthly frequencyof males and femalesin different stages of gonadal maturation. Maturing and mature fish occurred during most of the months, where as immature females occurred only in February. During this study there was predominance of mature males and females.
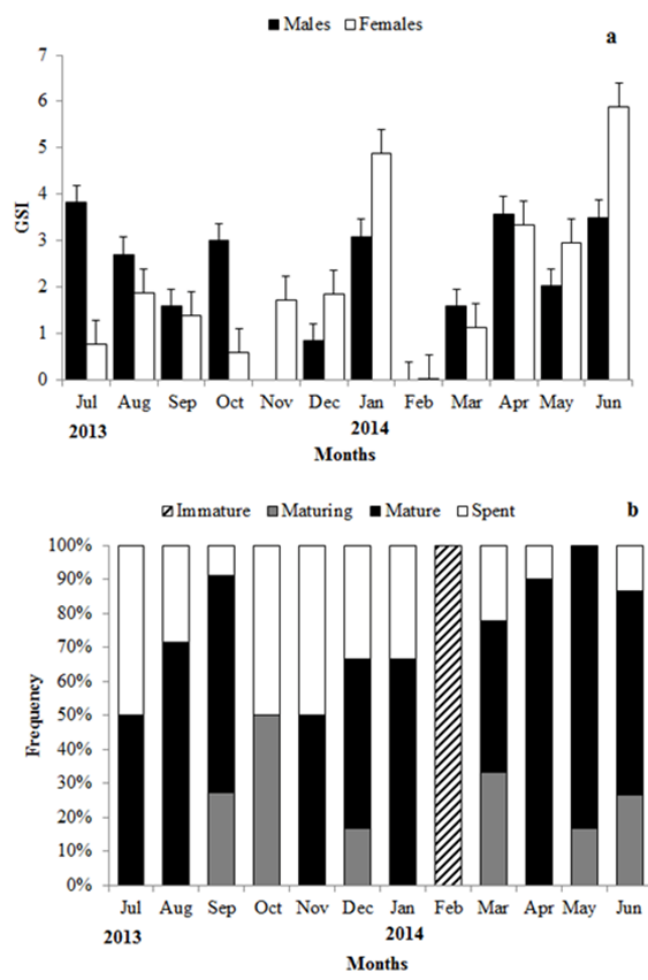

Figure 5 (a)Temporal distribution of GSI $( \pm S E)$ of males and females Caranxcrysos, and (b) monthly frequency of maturity stages of males and females.

\section{Histological analyses of ovaries}

The microscopic stages of ovaries showed oocyte development constituting in two stages. The first or the pre-vitellogenic stage included the early and late primary growth and cortical alveoli. The second or vitellogenic stage included the partially yolked and advanced yolked phases.
Early and late primary growth: The oocytes did not contain yolk. Initially the nucleus had few nucleoli. With the development of the oocytes there was an increase in the number of nucleoli, which were seen near the periphery of the nucleus (Figure 6a). Cortical alveoli: Cortical alveoli begin to accumulate in the cytoplasm. Yolk granules are still absent, but small oil droplets begin to accumulate and disperse in the cytoplasm. Partially yolkedstage (vitelogenic growth): During this stage yolk deposition initiated in the cytoplasm. Later the yolk granules and the oocyte begin to fill with protein yolk granules (Figure 6b).Late yolked stage (vitelogenic growth): The protein granules increase in number and fill the cytoplasm. The oil globules increase in size and were distributed around the nucleus (Figure $6 \mathrm{c}$ and 6d).
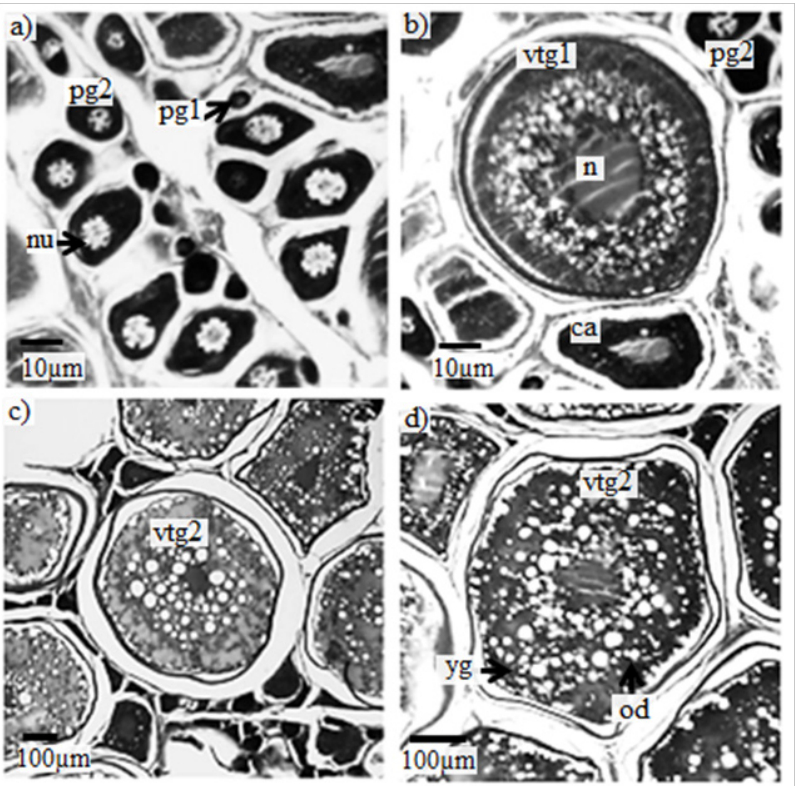

Figure 6 Photomicrographs of histological preparations from a cross-section of the gonad of femaleCaranxcrysos, showing oocyte development stages. (a) Developingoocyte $(\mathrm{Pgl})=$ early primary growth, $(\mathrm{Pg} 2)=$ late primary growth, nu=nucleoli; (b) Partially yolkedstage $(\mathrm{CA}=$ cortal alveolar; vtgl $=$ early vitelogenesis; (c and d)Late yolked stages(vtg2 = late vitelogenesis). $\mathrm{N}=$ nucleus; nu=nucleoli; $y g=y o l k$ granules; od $=$ oil droplets.Scale bar: $(a$ and $b=$ $10 \mu)(c$ and $d=100 \mu)$. Stained with Hematoxylin-Eosin (HE) and periodic acid Schiff (PAS).

\section{Fecundity}

The fecundity of $C$. crysos varied from 164782 to 542278 with an average of $408606(\mathrm{SD} \pm 172908)$ vitellogenic oocytes. The diameter of mature oocytes ranged from $250 \mu$ to $400 \mu$ with a mean of $350 \mu$ $( \pm 50.2)$.

\section{Monthly distribution of maturity stages and reproductive period}

GSI demonstrated the functional gonadal status in relation to fish body weight, indicating the spawning period. The mean monthly values of GSI varied from 0.84 to $3.82(2.33 \pm 1.23)$ for males and from 0.02 to $5.89(2.19 \pm 1.76)$ for females. Mature fish occurred during most part of the year, other than in the months of February and October. $C$. crysos has a prolonged reproductive period with peak period of activity during June and July (Figure 5).

\section{Discussion}

The general pattern of developmental stages of the gonads of $C$. crysos conforms to that of teleost fish. ${ }^{25,26}$ There are reports on the 
reproductive biology of C. crysos from the Eastern Mediterranean, ${ }^{4}$ from Porto Rico, ${ }^{10}$ from the Gulf of Mexico, ${ }^{11}$ from the Egyptian Mediterranean Sea, ${ }^{12}$ however there is scarcity of information on the reproductive biology of this species from Southwest Atlantic Ocean.

C. crysosreach a maximum length of $700 \mathrm{~mm}$ and $5.05 \mathrm{~kg}$ in weight, but is much more common below $350 \mathrm{~mm}$. In Florida it is usually captured at $300 \mathrm{~mm}$ of length. ${ }^{27}$ C. crysos sampled in the central Atlantic Mediterranean of Gulf of Gabes, the total length of females varied from 153 to $347 \mathrm{~mm}$ and that of males from 146 to $349 \mathrm{~mm} .{ }^{28}$ In the present study, the females of C. crysos were frequent in the total length classes of 320-340 and 340-360 mm and males in the classes of 340-360 and 360-380 mm. Individuals smaller than 200 $\mathrm{mm}$ of total length tend to inhabit shallower reefs and lagoon waters. There was no predomination of either sex of C. crysos during this study period. More females were present in the adult population in the Gulf of Mexico. ${ }^{29}$ However, in the Gulf of Gabesthere was predominance of males. ${ }^{4}$ Monthly and seasonal changes in the numerical proportions and the predominance of males or females can be related to the sample size frequency distribution or feeding behavior of each sex. The sex ratio of the population changes when the capture is selective for the size and sex of fish. ${ }^{4}$ In this study males and females of $C$. crysos showed no significant difference in the bodysize and weight, which may relate to non-selectivity of capture of individuals.

The value of $b$ of the length-weight ratio is within the expected range of 2.5 to $3.5 .{ }^{14}$ Thus, the negative allometric growth indicates that the body increases in length than by weight during growth. ${ }^{30}$ For the same species studied in the central Mediterranean, the allometric coefficient was 3.03 for males and for females was 3.04, indicating isometric growth. ${ }^{28}$ In general, parameters of the LW relationships in fish are affected by factors such as environmental conditions, maturation stages, sex, stomach fullness, health condition, season, population and differences within species. ${ }^{14}$

The blue runner reaches sexual maturity at slightly different lengths throughout its distribution range, generally between 225 and $280 \mathrm{~mm}$ of body length. Research in northwest Florida found a length at maturity of $267 \mathrm{~mm}$, a study in Louisiana showed that this species reaches sexual maturity at 247 to $267 \mathrm{~mm}$ in females and $225 \mathrm{~mm}$ in males, and in Jamaica lengths of $260 \mathrm{~mm}$ for males and $280 \mathrm{~mm}$ for females were estimated. ${ }^{11}$ Males of C. crysos in the Gulf of Gabes, Tunisia, reach their first sexual maturity at $212 \mathrm{~mm}$, and females with $223 \mathrm{~mm} .{ }^{4}$ All males were mature at $340 \mathrm{~mm}$ Fork Length and females at $360 \mathrm{~mm} \mathrm{FL} .{ }^{10}$ The smallest mature male and female were $283 \mathrm{~mm}$ and $28 \mathrm{~mm}$ in total length respectively. ${ }^{4}$ This study registers the mean size when $50 \%$ of fish were in the process of sexual maturation (L50) was $331 \mathrm{~mm}$ of total body length.

Spawning of C. crysos occurs offshore year round, ${ }^{11}$ although several peaks in spawning activity have been registered in different areas. Peak spawning season in the Gulf of Mexico occurs from June to August, with a secondary peak in spawning during October in northwest Florida. ${ }^{27}$ The IGS data of C. crysos in Puerto Rico shows a spawning period which extends from March to October, with a peak in May and June. ${ }^{10}$ In the Gulf of Gabes, IGS of C. crysos increases slightly in late spring and present peaks from July to August, which is influenced by the increase in temperature in the region. ${ }^{4}$ The effects of geographic variation on the reproductive variables can explain differences in reproductive activity of fish. These effects have been attributed to phenotypic plasticity resulting from abiotic factors, such as, temperature, rainfall and food availability. ${ }^{31}$

This study indicates that $C$. crysos presents prolonged reproductive activity, facilitating its population increase. Knowledge of the reproduction of C. crysos in the SouthwestAtlantic Ocean is crucial for the development of fishery management strategies. Adequate information on its reproduction is required to facilitate the fishery management. Thus, the present study gives basic information on the reproductive biology of C. crysos by investigating the size at maturity as well as the fecundity and reproductive cycle.

\section{Acknowledgements}

The authors wish to thank the National Council for Scientific and Technological Development (CNPq) and the Post Graduate Federal Agency of the Ministry of Education, Brazil (CAPES/MEC) for the financial support awarded during the study period. The authors are indebted to the artisanal fishermen who helped to capture fish during the study period.

\section{Conflicts of interest}

None.

\section{References}

1. Duarte MR, Tubino RA, Monteiro-Neto C, et al. Genetic and morphometric evidence that the jacks (Carangidae) fished off the coast of Rio de Janeiro (Brazil) comprise four different species. BiochemicalSystematics and Ecology. 2017;71:78-86.

2. Lessa R, Nóbrega MF. Guia de identificação dos peixes marinhos da região nordeste. Departamento de Pesca, UNIFPE, Programa Revizee / Score Nordeste. Brazil. 2000;pp.138

3. Pavicic M, Siljic J, Dugandzic P, et al. New record of blue runner, Caranx crysos(Mitchill, 1815), in the Adriatic Sea. Croatian Journal of Fisheries. 2014;72:125-127.

4. Sley A, Jarboui O, Ghorbel M, et al. Annual reproductive cycle, spawning periodicity and sexual maturity of blue runner Caranx crysos(Pisces, Carangidae) from the Gulf of Gabes (Tunisia, Eastern Mediterranean). Journal of Applied Ichthyology. 2012;28(5):785-790.

5. Andrades R, Pinheiro HT, Santos RG, et al. A new record of whale shark Rhincodon typus in Brazilian waters: a report of association with Caranx crysos. Journal of Fish Biology. 2012;81(6):2092-2094.

6. Murua H, Saborido-Rey F. Female reproductive strategies of marine fish species of the North Atlantic. Journal of Northwest Atlantic Fishery Science. 2003;33:23-31.

7. Chellappa S, Lima JTAX, Araujo A, et al. Ovarian development and spawning of Serra Spanish mackerel in coastal waters of Northeastern Brazil. Brazilian Journal of Biology. 2010;70(2):451-456.

8. Oliveira MR, Chellappa S. Temporal dynamics of Reproduction in Hemiramphus brasiliensis(Osteichthyes: Hemiramphidae). Scientific World Journal. 2014;2014:837151.

9. Oliveira MR, Carvalho MM, Silva NB, et al. Reproductive aspects of the flyingfish, Hirundichthy saffinis from the Northeastern coastal waters of Brazil. Braz J Biol. 2015;75(1):198-207.

10. Figuerola-Fernández M, Pena-Alvarado N, Torrez-Ruiz W. Aspects of the reproductive biology of recreationally important fish species in Puerto Rico. Puerto Rico: US Fish and Wildlife Service. 2008;pp.134.

11. Goodwin JM, Finucane JH. Reproductive biology of blue runner Caranx crysos from the eastern Gulf of Mexico. Northeast Gulf Science. $1985 ; 7(2): 139-146$.

12. Assem SS. The reproductive biology and histological characteristics of pelagic Carangid female Caranx crysos, from the Egyptian Mediterranean Sea. Journal of the Egyptian-German Society of Zoology. 2000;31(C):195-215.1 
13. Carpenter KE, Niem VH. The living marine resources of the Western Central Pacific. Volume 4: Bony fishes part 2 (Mugilidae to Carangidae). FAO Species Identification Guide for Fishery Purposes. 1998;20692790 .

14. Froese R. Cube law, condition factor and weight-length relationship: history, meta-analysis and recommendations. Journal of Applied Ichthyology. 2006;22(4):241-253.

15. Huxley JS. Constant differential growth-ratios and their significance. Nature. 1924;14:896-897.

16. Chen Y, Paloheimo JE. Estimating fish length and age at $50 \%$ maturity using a logistic type model. Aquatic Science. 1994;56(3):206-219.

17. West G. Methods of assessing ovarian development in fishes: a Review. Australian Journal of Marine and Freshwater Research. 1990;41:199_ 222.

18. Wallace RA, Selman K. Cellular and dynamic aspects of oocyte growth in teleosts. American Zoologist. 1981;21(2):325-343.

19. Brown-Peterson NJ, Wyanski DM, Saborido-Rey F, et al. A standardized terminology for describing reproductive development in fishes. Marine and Coastal Fisheries. 2011;3:52-70.

20. Hunter JR, Goldberg SR. Spawning incidence and batch fecundity in northern anchovy, Engraulis mordax. Fishery Bulletin US. 1980;77:641652

21. Murua H, Kraus G, Saborido-Rey F, et al. Procedures to estimate fecundity of marine fish species in relation to their reproductive strategy. Journal of Northwest Atlantic Fishery Science. 2003;33:33-54.

22. Wootton RJ, Evans GW, Mills LA. Annual cycle in female three-spined sticklebacks (Gasterosteu saculeatus L.) from an upland and lowland population. Journal of Fish Biology. 1978;12(4):331-343.
23. De Martini EE, FountainRK. Ovarian cycling frequency and batch fecundity in the queenfish. Seriphus politlls: Attributes representative of serial spawning fishes. Fishery Bulletin US. 1981;79:547-560.

24. McCullagh P, Nelder JA. Generalized Linear Models, (2nd edn), London: Chapman and Hall/CRC Press. 1989.

25. Zaki MI, Abu-Shabana MB, Assem SS. The reproductive biology of the saddled bream, Oblada melanura(L.1758) from the Mediterranean coast of Egypt. Oebalia. 1995;21:17-26.

26. Assem SS. The reproductive biology and the histological and ultrastructural characteristics of the ovary of the female pelagic fish Pagellu serythrinusfrom the Egyptian Mediterranean water. Journal of the Egyptian-German Society of Zoology. 2003;42:77-103.

27. Ohs CL, Creswell RL,Dimaggio MA. Growing marine baitfish: A guide to Florida's common marine baitfish and their potential for aquaculture. University of Florida/IFAS. Florida Sea Grant Publication. 2013.

28. Ghailen H, Abdallah H, Hassan A, et al. Length-weight relationships for 13 fish species from the Gulf of Gabes (Southern Tunisia, Central Mediterranean). African Journal of Biotechnology. 2010;9(37):61776181.

29. Goodwin JM, Johnson AG. Age, growth, and mortality of blue runner, Caranx crysos from the northern Gulf of Mexico. Northeast Guv Science. 1986;8(2):107-114.

30. Jobling M. Environmental factors and rates of development and growth In: Hart PJB, Reynolds JD (Eds.), Handbook of fish biology and fisheries. Fish biology. Blackwell, USA. 2002;pp.413

31. Wen H, Lin H. Effect of environmental factors on gonadal maturation as well as its ovulation and spawning in teleosts. Ying Yong Sheng Tai ХиеBao. 2001;12:151-155. 